\title{
MIGRACIJSKA KRIZA IN MIGRACIJSKA POLITIKA V EVROPI: OD DEMOGRAFSKIH NERAVNOVESIJ TER EKONOMSKE IN POLITIČNE NESTABILNOSTI DO NARAŠČAJOČIH MIGRACIJSKIH TOKOV
}

\author{
Janez MALAČIČ
}

COBISS 1.01

\section{IZVLEČEK}

Migracijska kriza in migracijska politika v Evropi: Od demografskih neravnovesij ter ekonomske in politične nestabilnosti do naraščajočih migracijskih tokov

Število migrantov iz Zahodne Azije in Severne Afrike v Evropo se je leta 2015 zelo povečalo. V Evropi je nastala velika migracijska kriza, ki jo je povzročila preusmeritev migrantskih poti iz južnih in zahodnih mediteranskih poti na balkansko pot. Razsežnost krize je pokazala nepripravljenost EU, da bi z ustrezno migracijsko politiko legalno obvladala nastali položaj. V Sloveniji smo v začetku množico migrantov le opazovali. Ko pa je Madžarska zaprla svoje meje, se je njihova pot preusmerila proti Sloveniji. Število migrantov, ki je hitro preseglo kapacitete, ki so omogočale nadzorovanje položaja, se je zmanjšalo šele spomladi 2016 po sprejetju dogovora med EU in Turčijo. Avtor zagovarja tezo, da je migracijska kriza v Evropi del širše krize prebivalstvene politike. Nedokončan demografski prehod v evropski soseščini s hitro rastjo prebivalstva, $\mathrm{z}$ vojnami in s političnimi krizami ustvarja vse več potencialnih migrantov. Ker se bodo demografska neravnovesja med temi regijami $\mathrm{v}$ prihodnosti še povečala, mora Evropa sprejeti primerno prebivalstveno in migracijsko politiko. Avtorjeve obrise vzdržne migracijske politike v EU bo treba preveriti v širših razpravah.

KLJUČNE BESEDE: migracijska kriza, migracijska politika, demografska neravnovesja, Evropska unija

\section{ABSTRACT}

Migrant Crisis and Migration Policy in Europe: From Demographic Imbalances and Political Turmoil to the Increasing Migration Stream

In 2015, migrations from West Asia and North Africa to Europe increased significantly. Migration streams to Europe predominantly changed directions from West and South Mediterranean to Balkan South East direction. Unprecedented migrant crisis has caused quick collapse of the European Union legal system dealing with immigration. The rules have been broken in Greece and some other European countries. Consequently, numerous undocumented immigrants have flooded Balkans and some other European countries in late 2015 and at the beginning of the next year. The number of migrants declined after the spring 2016 political agreement between the European Union and Turkey. The thesis of the paper is that migrant crisis is a part of broader population policy crisis in Europe. Differences in demographic transitions combined with political turmoil and local wars in emigration areas will generate lasting migration flows to Europe. Therefore, European Union and its member states need well designed and politically agreed population and migration policies. The author's ideas on sustainable European migration policy need further discussions and evaluations. KEY WORDS: migrant crisis, migration policy, demographic imbalances, European Union

Dr. ekonomije, upokojeni redni profesor, zunanji sodelavec Ekonomske fakultete Univerze v Ljubljani, Kardeljeva ploščad 17, SI-1000 Ljubljana; janez.malacic@ef.uni-lj.si 


\section{UVOD}

Število migrantov iz Zahodne (Z) Azije in Severne (S) Afrike v Evropo se je leta 2015 zelo povečalo. Poleti tega leta je zato $\mathrm{v}$ Evropi izbruhnila velika migracijska kriza, na katero niti Evropska unija (EU) niti širša Evropa nista bili pripravljeni. Moderna informacijska sredstva in množični mediji so objavljali fotografije beguncev, pomešanih z ekonomskimi migranti, ki so se iz številnih kriznih in vojnih žarišč v Z Aziji in Afriki podali preko Turčije na bližnje grške otoke in naprej po balkanski poti na Madžarsko in nekoliko pozneje tudi v Slovenijo. Njihov glavni cilj je bil priti v Nemčijo in druge bogate evropske države (in se izogniti revnim državam). Veliko število različnih nezakonitih imigrantov na balkanski poti v SZ Evropo, ki so bili pogosto brez kakršnihkoli dokumentov (Belloni 2016), je vzbudilo številne protislovne in pogosto čustvene reakcije evropske politične, strokovne in najširše družbene javnosti. Že precej dalj časa trajajoče tihotapljenje ljudi po morskih poteh čez Sredozemsko morje in dele Atlantskega oceana v EU, ki se je prav tako zelo povečalo po neuspehu "arabske pomladi« v Libiji in drugje v S Afriki in Z Aziji, v Evropi ni vzbudilo tako širokega in burnega odmeva, čeprav je v morju in na čolnih že takrat pogosto umrlo več sto nezakonitih migrantov. Evropa se ni ustrezno odzivala niti na številna kriminalna dejanja in zločine na čolnih, ki so izhajali iz odnosov med migranti in tihotapci ali pa med migranti samimi. Morje je pogoltnilo številne »brezimne« ljudi na njihovi poti v boljše življenje.

Balkanska pot se je leta 2015 nekoliko presenetljivo in sorazmerno pozno, glede na vojne v Iraku in Siriji, po spletu različnih okoliščin, ki jih bodo morali raziskovalci in politiki še podrobneje razložiti, na široko odprla. Veliko je k odprtju poti prispevala grška ekonomska kriza. Prezadolženost Grčije, neustrezno reševanje evrske krize s pretiranim varčevanjem in hudi mednarodni pritiski nanjo so prispevali $\mathrm{k}$ znižanju BDP, povečanju brezposelnosti, pa tudi $\mathrm{k}$ velikemu skrčenju javnega sektorja in hudi politični krizi. Tako Grčija ni imela več dovolj sredstev in politične volje, da bi dosledno spoštovala migracijsko zakonodajo EU in še naprej preprečevala prihod nezakonitih prebežnikov iz bližnje Turčije, preostale članice EU pa tudi niso zagotovile potrebnih sredstev. Begunski centri v Grčiji so popokali po šivih, nezakoniti migranti pa so v vse večjem številu prihajali čez makedonske in srbske meje, da bi čim prej prišli v šengensko območje EU, pa nekoliko pozneje tudi čez hrvaške. Takrat so po balkanski migracijski poti v osrčje EU začeli prihajati številni nezakoniti migranti, ki so v najboljšem primeru dobili začasna dovoljenja za prehod posameznih držav na njihovi poti v najbolj zaželene Nemčijo in druge bogate evropske države. Mobilni telefoni in drugi moderni pripomočki so novico o odprtju poti hitro prenesli $v$ begunska taborišča $v \mathrm{Z}$ Aziji in $\mathrm{v}$ Afriki in $\mathrm{s}$ tem omogočili izjemno naraščanje tihotapljenja ljudi. Pri tem je prihajalo do običajne selekcije; tihotapce lahko plačajo samo premožnejši med begunci in številni ekonomski migranti. Intenzivnost migracij se je spomladi leta 2016 zmanjšala. Število dnevnih prihodov iz Turčije v Grčijo je oktobra 2015 doseglo povprečno 6.929 oseb, do maja 2016 pa se je znižalo na povprečno 47 oseb dnevno. Zmanjšanje je bilo posledica dogovora med EU in Turčijo iz marca 2016, po katerem se je iz Grčije lahko vračalo nezakonite migrante brez urejenega statusa in prosilce za azil, $v$ zameno pa se je EU zavezala, da bo za vsakega vrnjenega Sirca sprejela Sirca, ki ni poskušal priti v EU na nezakonit način (Evropska komisija 2016: 2-3).

Raziskovalci migracij imamo premalo ustreznih statističnih podatkov o ljudeh, ki so po balkanski poti nezakonito in množično prihajali v Evropo, npr. o njihovi izobrazbi, 
državi porekla, etnični in verski pripadnosti ipd. Večina teh ljudi je bila brez uradno veljavnih potnih listin, bilo pa je tudi veliko prevar $\mathrm{z}$ identiteto in dokumenti. Ob razpadu urejenega pravnega migracijskega sistema je prišlo tudi do številnih uporov imigrantov, ki so nasprotovali popisovanju, odvzemu prstnih odtisov in kakršnikoli drugi statistiki v državah na njihovi poti. Ta sistem je na balkanski poti razpadel, to pa se je kazalo v nespoštovanju pravnega reda EU in dogovorjenih načinov urejanja migracij v okviru OZN. Pri tem sta se na vseh členih migracijske verige razbohotila tihotapljenje ljudi in služenje denarja z nezakonitimi migracijami. Po ocenah Europola je leta 2016 v Evropi delovalo okrog 30.000 tihotapcev ljudi, za Z Azijo in S Afriko pa ni niti okvirnih ocen njihovega števila. Njihovi zaslužki so (bili) veliki, tveganje pa majhno.

Po širšem uvodu prehajam h konkretnejšemu namenu pričujočega besedila. Zaradi dinamičnega dogajanja, nepopolnih statističnih podatkov in zamika med procesi in njihovo strokovno in znanstveno analizo $\mathrm{v}$ besedilu ne obravnavam podrobneje obsežnih nezakonitih migracij v letih 2015 in 2016 (v nadaljevanju 2015/16) po balkanski poti v Evropo. Namesto tega je kratek uvodni opis dogajanja podlaga za zagovarjanje teze, da je migracijska kriza v Evropi v drugem desetletju 21. stoletja predvsem kriza prebivalstvene politike EU in v Evropi nasploh. Migracijska politika je z vsemi svojimi deli eminenten del prebivalstvene politike, kar so evropske države in celotna EU v zadnjih dveh desetletjih po Konferenci OZN o prebivalstvu in razvoju v Kairu leta 1994 zanemarile. V nadaljevanju prikazujem širši demografski okvir migracijske krize v Evropi in njeni bližnji soseščini, v Z Aziji in v S Afriki. Besedilo sklenem s kratkim orisom vzdržnega modela migracijske politike EU v širšem okviru vzdržne prebivalstvene politike EU. V delu uporabljam kombinacijo induktivne in deduktivne znanstvene metode, ki mi ob uporabi kazalcev demografske in ekonomske statistike ter izbrane literature omogoča obravnavo teze in uresničitev zastavljenih ciljev.

\section{MIGRACIJSKA POLITIKA KOT DEL PREBIVALSTVENE POLITIKE}

Migracijska politika (MP) je pomemben sestavni del prebivalstvene politike (PP), kar izhaja že iz preprostega dejstva, da se PP ukvarja z vsemi demografskimi procesi (Malačič 2006: 274). Kompleksnost demografskih procesov in njihova medsebojna prepletenost pomembno prispevata $\mathrm{k}$ različnim pogledom na PP (Demeny 2003) in njene različne definicije. Vendar je MP zmeraj vključena v PP, ne glede na to, če na slednjo gledamo z ožjega (z vidika rodnosti in smrtnosti) ali s širšega vidika. Res pa je, da če na PP pogledamo širše, $\mathrm{Z}$ vidika medsebojne povezanosti in vpliva demografskega, ekonomskega in družbenega razvoja, postane MP še bistveno pomembnejša.

Ob družbenem dogajanju in politični praksi v različnih predelih sveta hitro ugotovimo, da se MP razume zelo ozko. Njena povezava s PP se ne le zanemarja, ampak pogosto celo zanika. Ta kratkovidnost pa se tukaj ne konča, ampak se enako izrazito prenaša na samo MP. Znotraj MP se najpogosteje zanemarja povezanost med imigracijami in emigracijami. Dobra primera tega sta slovenska Resolucija o imigracijski politiki iz leta 1999 (Ur. list RS, št. 40/99) in Resolucija o migracijski politiki R Slovenije iz leta 2002 (Ur. list RS, št. 106/02). Slednja sicer govori širše o MP, vendar je njeno težišče še vedno na imigracijskem vidiku MP. Ozko razumevanje migracij se kaže v odnosu do ekonomskih in nezakonitih migracij pa tudi do beguncev in različnih prosilcev za azil. Njihov pravni 
položaj je različen tako v mednarodnih okvirih pravnega urejanja te problematike kot tudi v posameznih državah ali skupnostih držav. Vse to se izraža tudi v v članku obravnavani evropski migracijski krizi.

MP je pod močnim vplivom ekonomskih, demografskih in družbenih razmer v emigracijskih in imigracijskih državah (Massey 2007). Večje so razlike med njimi, bolj pride do izraza osnovna težnja ljudi, da se selijo iz revnih v bogate države, pri čemer obstajajo številne omejitve. Med temeljnimi človekovimi pravicami namreč ni pravice, da bi si lahko svobodno izbirali kraj bivanja. V okviru OZN o tem govori Akcijski program konference o prebivalstvu in razvoju v Kairu leta 1994, po kateri ima človek sicer pravico izbire kraja bivanja, hkrati pa je pravica vsake države, da odloča o tem, kdo lahko vstopi na njeno ozemlje in pod kakšnimi pogoji lahko na njem biva (Akcijski program 1994: 60). Program pa pravi tudi, da bi si morale vlade držav prizadevati za ustvarjanje možnosti za vse ljudi, da ostanejo v svoji državi (prav tam: 57).

Možnosti vodenja učinkovite MP pa se med razvitimi in nerazvitimi državami zelo razlikujejo. Čeprav vse države uporabljajo sistem viz, različnih dovoljenj za bivanje, študij, delo in zaposlitev ter številne druge administrativne posege in omejitve, je rezultat v obeh skupinah držav praviloma različen. V razmerah relativno odprtih državnih meja je iz povsem ekonomskih razlogov lahko učinkovita samo imigracijska politika razvitih držav, ki praviloma vodijo selektivno MP. Naj v zvezi s tem povem le, da selekcija praviloma poteka na podlagi izobrazbe, šolanja, starosti, posebne usposobljenosti, podjetniških sposobnosti in talentov, športnih dosežkov, kulturnih in drugih tradicionalnih povezav med izvornimi in državami priseljevanja ipd. (Boeri idr. 2002: 49-52). Vendar tudi razvite države, tudi če bi to hotele, v praksi ne morejo zmanjšati ali celo odpraviti migracijskih tokov. Tudi podobe iz migracijske krize 2015/16 kažejo, da ograje in zidovi migracij ne morejo preprečiti ali celo zaustaviti. Razvite države bi morale za ustavitev migracij poseči po krutih in za demokratične države nesprejemljivih ukrepih odpovedi mednarodnih pogodb in konvencij. Kršiti pa bi morale tudi temeljne človekove pravice in poseči po različnih diskriminacijah. Danes je v svetu samo nekaj držav, npr. Severna Koreja, ki migracije preprečujejo na ta način.

Razvite države pa priseljevanja ne morejo in ne smejo ustaviti tudi iz povsem demografskih razlogov. Večina teh držav se v času po demografskem prehodu od visokih na nizke ravni rodnosti in smrtnosti sooča z nizko rodnostjo, ki skoraj nikjer ne zagotavlja niti enostavnega obnavljanja prebivalstva, v številnih državah pa se je rodnost še bolj znižala. Posledica nizke rodnosti je izrazito ali celo pretirano staranje prebivalstva, negativen naravni prirastek in v prihodnosti depopulacija večjih razsežnosti. Prenizko rodnost, pretirano staranje prebivalstva in depopulacijo večjih razsežnosti je laže omiliti ali celo odpraviti s priseljevanjem iz nerazvitih držav, kot pa pričakovati, da se bo rodnost v razvitih državah, bodisi avtonomno ali pa s pomočjo učinkovite politike spodbujanja rodnosti, dvignila na raven, ki bo zagotavljala dolgoročno nemoteno obnavljanje prebivalstva. Za razvite države bi bilo s tega vidika najugodneje, če bi vzdržno obnavljanje dosegle kombinirano, to je $\mathrm{z}$ dvigom domače rodnosti vsaj na raven $\mathrm{T}_{\mathrm{f}} 1,8$ do 1,9 in s postopnim zmernim priseljevanjem, kar bi omogočilo primerno integracijo imigrantov in s tem tudi politično sprejemljivost priseljevanja. Vse to najlepše pokaže, kako je MP v resnici izredno pomemben del PP. 


\section{ŠIRŠI DEMOGRAFSKI OKVIRI MIGRACIJSKE KRIZE V EVROPI IN ZAHODNI AZIJI TER SEVERNI AFRIKI}

Migracijska kriza sredi tega desetletja je zlasti zanimiva z vidika demografskih razlik med Evropo na eni in Z Azijo in S Afriko na drugi strani; te regije uporabljam po definicijah OZN. Evropa vključuje tudi Rusijo, k Z Aziji spada 18 držav, vključno s Ciprom, Turčijo, z Gruzijo, Armenijo, Azerbajdžanom in Irakom, vendar brez Irana, k S Afriki pa spada sedem držav, vključno s Sudanom in z Z Saharo. Demografske razlike med Evropo in njenim ožjim azijskim in afriškim zaledjem lahko najkrajše označimo z razlikami v demografskih režimih (DR) obnavljanja prebivalstva med temi regijami. V Evropi, kjer je demografski prehod končan, se je že sredi 20. stoletja oblikoval moderni DR z nizko smrtnostjo in rodnostjo, nizkim ali celo negativnim naravnim prirastkom, s staranjem prebivalstva in pozitivnimi neto migracijami. V Z Aziji in S Afriki pa demografski prehod še poteka, zato je tam prehodni DR. Smrtnost se je sorazmerno hitro znižala, rodnost pa se znižuje počasneje, kar vodi do hitre rasti prebivalstva. Neto migracije so negativne, starostna struktura prebivalstva pa izrazito mlada. Če k temu dodamo veliko razliko v gospodarski razvitosti med regijami, je jasno, da so v Z Aziji in S Afriki številni potencialni migranti, ki si želijo v Evropo. Sorazmerno velike migracije v Evropo potekajo že v normalnih razmerah, med vojnami in širšimi družbenimi krizami, ki jih sprožijo različna "pomladna« in druga gibanja, pa nenadoma nastanejo razmere, ki povzročijo masovne migracije in celo eksodus.

Odzivi množičnih medijev pa tudi evropske politične in najširše javnosti na migracijsko dogajanje na Balkanu in na poti proti osrednjemu delu Evrope v letih 2015/16 so praviloma prezrli demografsko realnost in velike razlike med Evropo in njenim zaledjem, ki se bodo v prihodnosti še poglobile. Za tri obravnavane regije OZN so na voljo zelo različni demografski statistični podatki. Ker so podatki za Evropo odlični (European Data Sheet 2014), za njeno zaledje pa veliko slabši, še zlasti za države v vojni, tukaj uporabljam podatke OZN, ki tudi za manj razvite in krizne države pripravljajo najboljše možne ocene. S pomočjo realnih podatkov, ocen in projekcij obravnavam stoletno obdobje 1950-2050, kar omogoča OZN z več desetletji trajajočim ocenjevanjem in projiciranjem podatkov o prebivalstvu za svet, njegove regije in posamezne države. Zadnja verzija dela, znanega kot World Population Prospects (WPP), je na voljo za leto 2015 (WPP 2015 Revision). Izbrani demografski podatki za tri obravnavane regije so prikazani v Tabeli 1. 
Tabela 1: Izbrani demografski podatki za S Afriko, Z Azijo in Evropo za leta 1950, 2015 in $2050^{1}$

\begin{tabular}{|c|c|c|c|c|c|c|c|c|c|}
\hline \multirow{2}{*}{$\begin{array}{c}\text { IZBRANI } \\
\text { KAZALEC }\end{array}$} & \multicolumn{3}{|c|}{ Severna Afrika } & \multicolumn{3}{c|}{ Zahodna Azija } & \multicolumn{3}{c|}{ Evropa } \\
\cline { 2 - 11 } & 1950 & 2015 & 2050 & 1950 & 2015 & 2050 & 1950 & 2015 & 2050 \\
\hline P v mio & 49,2 & 223,9 & 354,3 & 51,0 & 257,2 & 395,5 & 549,1 & 738,4 & 706,8 \\
\hline $\begin{array}{c}\text { Mediana } \\
\text { starosti }\end{array}$ & 19,9 & 25,1 & 32,2 & 20,8 & 26,3 & 34,3 & 28,9 & 41,7 & 46,2 \\
\hline $\mathbf{r v \%}$ & 2,5 & 1,9 & 0,9 & 2,6 & 2,0 & 0,7 & 1,0 & 0,1 & $-0,2$ \\
\hline j v\%o & 26,2 & 20,7 & 8,9 & 24,8 & 17,6 & 7,4 & 10,3 & $-0,3$ & $-3,6$ \\
\hline $\begin{array}{c}\text { Ekonomska } \\
\text { odvisnost }\end{array}$ & 75,6 & 59,7 & 56,8 & 73,0 & 54,3 & 55,3 & 52,2 & 50,0 & 74,6 \\
\hline $\mathbf{T}_{\mathbf{f}}$ & 6,7 & 3,3 & 2,3 & 6,3 & 2,9 & 2,2 & 2,7 & 1,6 & 1,8 \\
\hline $\mathbf{e}_{\mathbf{0}, \mathbf{m}}$ & 41,4 & 68,8 & 75,7 & 41,6 & 70,0 & 77,2 & 60,9 & 73,4 & 80,1 \\
\hline $\mathbf{e}_{\mathbf{0}, \mathbf{f}}$ & 43,2 & 72,4 & 79,4 & 46,3 & 75,6 & 81,2 & 66,1 & 80,6 & 85,6 \\
\hline $\mathbf{n m} \mathbf{v} \% \mathbf{m}$ & $-1,4$ & $-1,9$ & $-0,3$ & 1,4 & 2,5 & 0,1 & $-0,5$ & 1,1 & 1,2 \\
\hline
\end{tabular}

Vir: WPP 2015 Revision, UN, Population Division

Tukaj ne morem podrobno obravnavati vseh demografskih razlik med Evropo in zaledjem. Očitno pa je, da postopno dokončanje demografskega prehoda v zalednih regijah do leta 2050 ne bo odpravilo razlik, ampak bo mnoge še poglobilo. Največje nesorazmerje, ki je za pričujoče besedilo tudi najpomembnejše, je v rasti prebivalstva (Lutz idr. 2003). V sto letih se bo po srednji varianti projekcij OZN prebivalstvo $\mathrm{V} Z$ Aziji predvidoma povečalo $\mathrm{Z}$ indeksom 775,5, v S. Afriki s 720,1 in v Evropi s 128,7. Če upoštevamo, da se zaledni regiji tudi zaradi vojn in politične nestabilnosti ekonomsko počasi razvijata, se bo migracijski pritisk na Evropo v prihodnjih desetletjih še stopnjeval. Nekatere od preostalih razlik se bodo zmanjšale, druge pa povečale ali pa bodo okvirno ostale enake kot leta 2015. Zmanjšale se bodo predvsem razlike $\mathrm{v}$ ravni rodnosti in smrtnosti ter $\mathrm{v}$ naravnem prirastku in rasti prebivalstva. Razlike v mediani starosti prebivalstva se bodo še povečale.

Pri neto migracijah je slika pestrejša. Leta 1950 je bila celo Evropa emigracijska. Na splošno pa sta Evropa in Z Azija v izbranih letih regiji s pozitivnimi, S Afrika pa z negativnimi neto selitvami. Zanimivo je, da se bo ekonomska odvisnost v sto letih obrnila na glavo. V Evropi bo leta 2050 kazalec približno tolikšen, kot je bil leta 1950 v zaledju, vendar bo struktura tega kazalca bistveno različna, saj bodo v Evropi leta 2050 odvisni predvsem stari, v zaledju pa so bili leta 1950 odvisni predvsem otroci.

1 S Afrika zajema Alžirijo, Egipt, Libijo, Maroko, Sudan, Tunizijo in Z Saharo; Z Azija zajema Armenijo, Azerbajdžan, Bahrajn, Ciper (tukaj zanemarimo, da je grški del Cipra članica EU), Gruzijo, Irak, Izrael, Jordanijo, Kuvajt, Libanon, Oman, Katar, Saudsko Arabijo, Palestino, Sirijo, Turčijo, Združene arabske emirate in Jemen; Evropa zajema tudi Rusijo. Za leto 2050 so podatki po srednji varianti projekcij OZN. Mediana starosti ter življenjski pričakovanji ob rojstvu za moške in ženske, $\mathrm{e}_{0, \mathrm{~m}}$ in $\mathrm{e}_{0, \mathrm{f}}$, so $\mathrm{v}$ letih. $\mathrm{r}$ in $\mathrm{j}$ sta letni stopnji rasti prebivalstva (P) in naravnega prirastka, $\mathrm{T}_{\mathrm{f}}$ je stopnja totalne rodnosti $\mathrm{v}$ številu otrok na žensko, nm je stopnja neto migracij, ekonomska odvisnost je razmerje med vsoto $\mathrm{P}_{0-14}$ in $\mathrm{P}_{65+} \mathrm{v}$ števcu ter $\mathrm{P}_{15-64}$ v imenoval$\mathrm{cu}$. Intervalni podatki, npr. $\mathrm{r}$ in $\mathrm{nm}$, so za petletje, ki sledi navedenemu letu v glavi tabele. 
Za podrobnejše poznavanje demografskih razmer v bližnjem evropskem zaledju v Tabeli 2 prikazujem štiri demografske podatke za leti 2015 in 2050 za izbrane (večje) države iz zalednih regij. Ti štirje podatki so število prebivalstva $(\mathrm{P})$, mediana starosti prebivalstva v letih ter naravni prirastek in neto migracije v odtisočkih. Tudi ti podatki so iz WPP 2015. Za leto 2050 pa so podatki po srednji varianti projekcij OZN, ki se nahajajo med bolj skrajnima nizkima in visokima variantama.

Tabela 2: Število prebivalstva (P), mediana starosti (v letih), naravni prirastek v odtisočkih in neto migracije v odtisočkih za leti 2015 in 2050 za izbrane (večje) države S Afrike in Z Azije ${ }^{2}$

\begin{tabular}{|c|c|c|c|c|c|c|c|c|}
\hline \multirow{2}{*}{ Država } & \multicolumn{2}{|c|}{$\begin{array}{c}\text { Število } \\
\text { prebivalstva }\end{array}$} & \multicolumn{2}{c|}{$\begin{array}{c}\text { Mediana starosti } \\
\text { (v letih) }\end{array}$} & \multicolumn{2}{c|}{$\begin{array}{c}\text { Naravni } \\
\text { prirastek v \%o }\end{array}$} & \multicolumn{2}{c|}{$\begin{array}{c}\text { Neto migracije } \\
\text { v \%o }\end{array}$} \\
\cline { 2 - 10 } & 2015 & 2050 & 2015 & 2050 & 2015 & 2050 & 2015 & 2050 \\
\hline Egipt & 91,5 & 151,1 & 24,7 & 31,0 & 22,3 & 9,8 & $-0,5$ & $-0,3$ \\
\hline Turčija & 78,7 & 95,8 & 29,8 & 41,8 & 11,5 & 1,7 & 5,3 & $-0,1$ \\
\hline Sudan & 40,2 & 80,3 & 19,4 & 26,2 & 25,8 & 14,3 & $-4,2$ & $-0,1$ \\
\hline Alžirija & 39,7 & 56,5 & 27,6 & 37,1 & 19,9 & 5,7 & $-0,8$ & $-0,2$ \\
\hline Irak & 36,4 & 83,7 & 19,3 & 24,3 & 29,8 & 18,5 & 3,3 & $-0,1$ \\
\hline Maroko & 34,4 & 43,7 & 28,0 & 38,6 & 15,5 & 3,3 & $-1,9$ & $-1,3$ \\
\hline Savdska & 31,5 & 46,1 & 28,3 & 38,2 & 17,4 & 3,3 & 5,7 & 0,8 \\
\hline Arabija & 26,8 & 47,2 & 19,3 & 29,6 & 26,1 & 8,5 & $-0,4$ & $-0,4$ \\
\hline Jemen & 18,5 & 34,9 & 20,8 & 33,7 & 18,5 & 6,7 & $-41,1$ & $-0,3$ \\
\hline Sirija & 11,3 & 13,5 & 31,2 & 40,4 & 11,8 & 1,3 & $-0,6$ & $-0,3$ \\
\hline Tunizija & 8,1 & 12,6 & 30,3 & 35,2 & 16,1 & 8,8 & 0,5 & 0,7 \\
\hline Izrael & 7,6 & 11,7 & 22,5 & 32,4 & 24,0 & 8,7 & 6,5 & $-0,3$ \\
\hline Jordanija & 6,3 & 8,4 & 27,5 & 38,4 & 16,4 & 1,9 & $-16,0$ & 0,5 \\
\hline Libija & 5,9 & 5,6 & 28,5 & 46,8 & 10,3 & 1,4 & 49,1 & $-0,7$ \\
\hline Libanon & 4,7 & 9,8 & 19,3 & 27,4 & 29,5 & 15,3 & $-2,0$ & $-0,5$ \\
\hline Palestina & $7,6,3$ \\
\hline
\end{tabular}

Vir: WPP 2015, Revision, UN, Population Division

Podatki v Tabeli 2 podrobneje kažejo demografske razlike med posameznimi izbranimi državami v S Afriki in Z Aziji in s tem dopolnjujejo Tabelo 1. Po srednji varianti projekcij OZN naj bi se do leta 2050 prebivalstvo več kot podvojilo v Iraku, Jemnu in Palestini, zelo blizu podvojitve pa sta še Sudan in Sirija. To so države z najvišjim naravnim prirastkom leta 2015 in hkrati države, ki so v vojni ali veliki politični krizi. V takih razmerah ni gospodarskega in družbenega razvoja, ki bi krepil procese modernizacije in s tem demografski

2 Za leto 2050 so podatki po srednji varianti projekcij OZN. V skladu s stališčem OZN je Palestina prikazana kot samostojna država. 
prehod. Rang držav po številu prebivalstva se do leta 2050 po projekcijah predvidoma ne bo veliko spremenil. Egipt bo ostal na prvem mestu s kar 151,1 milijona ljudi, Irak se bo uvrstil na tretje mesto, Jemen bo prehitel Maroko in Savdsko Arabijo, slednja pa Maroko. Omenjam še Palestino, ki bo z blizu 10 milijoni ljudi prehitela Libijo in Libanon. Ob današnjih zaostrenih političnih razmerah v obeh obravnavanih regijah, zaostajanju arabskega sveta za razvojem v svetu in grozečih klimatskih spremembah, ki s segrevanjem planeta dvigujejo temperature, si je težko predstavljati, kako bo v prihodnjih desetletjih v S Afriki in Z Aziji živelo tako veliko število ljudi.

Konec demografskega prehoda bo v obdobju do leta 1950 privedel do modernega DR v Turčiji, Tuniziji in Libanonu. Izraela tukaj posebej ne obravnavam, saj je tam demografski prehod že končan. V drugih obravnavanih državah se zdi, da se bo prehodni DR še podaljšal, čeprav ni izključeno, da bi nekatere države pospešeno končale demografski prehod; kandidata sta predvsem Alžirija in Maroko. Migracijska slika, ki jo praviloma kažejo ocenjeni podatki o neto migracijah v Tabeli 2, je bolj kompleksna, kot bi pričakovali glede na prevladujoči DR. Negativne neto migracije v stolpcu za leto 2015 sicer prevladujejo, vendar je hkrati kar šest držav s pozitivnimi neto migracijami. Razumljivo je, da bogata Savdska Arabija privlači priseljence, čeprav ni pripravljena sprejeti beguncev iz soseščine ali pa se ji ti izogibajo. Jordanija, Libanon in Turčija so sprejeli veliko beguncev iz Sirije. Bolj negotov pa je podatek za Irak, čeprav je lahko rezultat relativne umiritve razmer v njegovem šiitskem in deloma kurdskem delu. Srednja varianta projekcij OZN za leto 2050 predvideva umiritev razmer in večjo prevlado neto odseljevanja.

Pri obravnavi migracijskih razmer pa se moramo zavedati, da lahko hitro pride do velikih sprememb. Izbruh vojne ali večja politična kriza lahko v kratkem času bistveno spremenita razmere. Po ocenah avstrijskih demografov je imela Sirija v letih 2005-2010 397.000 priselitev in 452.000 odselitev ter negativne neto selitve v obsegu 55.000 (Global Migration Data Sheet 2014), kar pa se je v naslednjih petih letih zaradi vojne povsem spremenilo. Dunajski podatki tudi kažejo, da je bilo v absolutnem številu največ neto odseljevanj iz Maroka, Egipta, Alžirije, Iraka in Jemna, največ neto priseljevanj pa v bogate zalivske države na Arabskem polotoku. V Tabeli 3 še dodatno prikazujem površino, podrobnejše izbrane demografske kazalce in bruto nacionalni dohodek (BND) na prebivalca, popravljen s pariteto kupne moči, ki na uveljavljeni statistični način izboljšuje mednarodno primerljivost podatkov o BND za iste države kot $\mathrm{v}$ Tabeli 2. BND je izražen $\mathrm{v}$ ameriških dolarjih in se nanaša na leto 2014, preostali podatki pa so za leto 2015. Izbrani demografski podatki so francoski strokovnjaki ocenili na podlagi krajšega obdobja zadnjih let (Pison 2015: 1) in se deloma razlikujejo od podatkov, prikazanih v Tabeli 2, hkrati pa so rezultat stiske zaradi pomanjkanja dobrih statističnih podatkov.

Podatki v Tabeli 3 kažejo velike razlike v BND na prebivalca v izbranih državah. Razlike $\mathrm{v}$ površini posameznih držav zaradi prisotnosti puščavskih ozemelj zanemarjam. BND na prebivalca je največji v državah, bogatih z nafto. Preostale obravnavane države, če ne upoštevam Izraela, pa po ekonomski razvitosti precej zaostajajo. To zaostajanje bo v prihodnjih desetletjih skupaj z nedokončanim demografskim prehodom, ki je še dodatno osvetljen z demografskimi kazalci v Tabeli 3, temeljni ekonomski dejavnik rasti števila potencialnih migrantov iz S Afrike in Z Azije v Evropo. Nadaljevanje sedanjih političnih kriz in vojn ter morebitni nastanek novih pa bo v kombinaciji z nižjo ekonomsko razvitostjo in s hitro rastjo števila prebivalstva še dodatno zaostrovalo razmere. 
Tabela 3: Površina in izbrani demografski kazalci v letu 2015 ter bruto nacionalni dohodek na prebivalca v USD po pariteti kupne moči za leto 2014 za izbrane (večje) države S Afrike in Z Azije ${ }^{3}$

\begin{tabular}{|c|c|c|c|c|c|c|c|c|}
\hline $\begin{array}{l}\text { Regija, } \\
\text { Država }\end{array}$ & $\begin{array}{c}\text { Površina } \\
\text { v tisoč } \\
\text { km² }^{2}\end{array}$ & $\begin{array}{c}\mathrm{T}_{\mathrm{f}} \mathrm{v} \text { št. } \\
\text { otrok na } \\
\text { žensko }\end{array}$ & $\begin{array}{c}\mathbf{m}_{0} \\
(\mathrm{v} \\
\%)\end{array}$ & $\begin{array}{l}P_{0-14} \\
(\mathbf{v} \%)\end{array}$ & $\begin{array}{c}P_{65+} \\
(\mathbf{v} \%)\end{array}$ & $\begin{array}{l}\mathbf{e}_{0, \mathrm{~m}} \\
\mathbf{v} \\
\text { letih }\end{array}$ & $\begin{array}{c}e_{0, f} \\
v \\
\text { letih }\end{array}$ & $\begin{array}{c}\text { BND v } \\
\text { PKM na } \\
\text { preb. }\end{array}$ \\
\hline \multicolumn{9}{|c|}{ Severna Afrika } \\
\hline Egipt & 1.001 & 3,5 & 22 & 31 & 4 & 70 & 73 & 11.020 \\
\hline Sudan & 1.861 & 5,2 & 52 & 43 & 3 & 60 & 64 & 3.980 \\
\hline Alžirija & 2.382 & 3,0 & 21 & 28 & 6 & 72 & 77 & 13.540 \\
\hline Maroko & 447 & 2,5 & 26 & 25 & 6 & 73 & 75 & 7.180 \\
\hline Tunizija & 164 & 2,1 & 16 & 23 & 8 & 74 & 78 & 10.600 \\
\hline Libija & 1.760 & 2,4 & 14 & 29 & 5 & 69 & 74 & 16.190 \\
\hline \multicolumn{9}{|c|}{ Zahodna Azija } \\
\hline Turčija & 748 & 2,2 & 11 & 24 & 8 & 75 & 79 & 19.040 \\
\hline Irak & 438 & 4,2 & 37 & 41 & 3 & 67 & 71 & 14.670 \\
\hline $\begin{array}{l}\text { Savdska } \\
\text { Arabija }\end{array}$ & 2.150 & 2,9 & 16 & 30 & 3 & 73 & 75 & 53.760 \\
\hline Jemen & 528 & 4,4 & 43 & 41 & 3 & 62 & 67 & 3.820 \\
\hline Sirija & 185 & 2,8 & 16 & 33 & 4 & 64 & 76 & - \\
\hline Izrael & 22 & 3,3 & 3 & 28 & 11 & 80 & 84 & 32.550 \\
\hline Jordanija & 89 & 3,5 & 17 & 37 & 3 & 73 & 77 & 11.910 \\
\hline Libanon & 10 & 1,7 & 8 & 26 & 6 & 76 & 79 & 17.330 \\
\hline Palestina & 6 & 4,1 & 18 & 40 & 3 & 72 & 75 & - \\
\hline
\end{tabular}

Vir: Pison 2015: 2-4

Na velika demografska nesorazmerja med Evropo in njenimi sosednjimi regijami sem v preteklosti že večkrat opozarjal (Malačič 2009a; Malačič 2009b), čeprav si takrat nisem mogel predstavljati, da se v Evropi lahko pojavi tako veliko število beguncev in nezakonitih imigrantov, kot jih je bilo v letih 2015/16 na balkanski poti. Vzroki zanje so zelo kompleksni in povezani tako $\mathrm{z}$ razmerami na emigracijskem območju kot tudi z različnimi odzivi in ravnanji v Evropi in še zlasti v EU. Pri opozarjanju na demografska nesorazmerja ne smemo pasti v demografski determinizem in na emigracijskem območju zanemariti ekonomskih, političnih, kulturnih in drugih dogajanj. Hkrati pa se moramo zavedati, da so številne ekonomske, politične in vojne krize pogosto dodatno spodbujene s hitro rastjo števila prebivalstva in njegovo mlado starostno strukturo. Zaradi tega bi morali v vseh treh obravnavanih regijah, zlasti po letu 1994, ko je bila kairska konferenca OZN, bistveno več

$3 \mathrm{~T}_{\mathrm{f}}$ je v številu otrok na žensko; $\mathrm{m}_{0}$ je v številu umrlih dojenčkov na 1.000 živorojenih; $\mathrm{P}_{0-14}$ in $\mathrm{P}_{65+}$ sta v odstotkih od celotnega prebivalstva; $\mathrm{e}_{0, \mathrm{~m}}$ in $\mathrm{e}_{0, \mathrm{f}}$ sta življenjski pričakovanji ob rojstvu za moške in ženske; BND v PKM na prebivalca je v ameriških dolarjih (USD) za leto 2014. V skladu s stališčem OZN je Palestina prikazana kot samostojna država. 
pozornosti in energije posvetiti gradnji primerne PP in v njenem okviru še zlasti MP. To pa se doslej ni zgodilo v nobeni od treh regij. EU je v zadnjih dveh do treh desetletjih začela počasi sestavljati mozaik PP, čeprav je ta v pristojnosti držav članic, vendar dalj od zametkov ni prišla (Geddes 2001; Malačič 2013: 29-31; EC 2005a; EC 2005b; EC 2007; EK 2008). Sedanja migracijska kriza kaže, da dosedanja prizadevanja EU na področju MP niso kos naraščajočim migracijskim pritiskom iz bližnjega zaledja in drugih nerazvitih predelov sveta (Dossier Migration 2015: 34). Takšno politiko bi morala EU pospešeno oblikovati in sprejeti, saj jo zahtevajo tako gospodarska kot politična dogajanja v Evropi.

\section{OBRISI VZDRŽNEGA MODELA MIGRACIJSKE POLITIKE EU}

EU in njene članice si morajo prizadevati za uresničevanje MP, ki bo usklajena $\mathrm{z}$ načeli in okviri, sprejetimi na globalni ravni v okviru OZN, pri čemer morajo upoštevati Ustanovno listino OZN in širok mednarodni pravni okvir različnih konvencij in drugih dokumentov. Pri številnih konvencijah si je treba prizadevati za pridobitev dodatne podpore in s tem za njihovo uveljavitev. Na področju MP in PP je najpomembnejši mednarodni dokument AP že omenjene konference OZN v Kairu ter sklepi, ki so jih organi OZN sprejeli ob periodičnih obravnavah uresničevanja AP. Na demografskem področju se razlike med razvitimi in nerazvitimi državami poglabljajo: število prebivalcev v prvih stagnira, v drugih še vedno hitro raste, hkrati pa se večajo razlike med državami in regijami v skupini nerazvitih. Evropa in EU bosta morali upoštevati, da bo v 21. stoletju najhitreje naraščalo prebivalstvo Afrike. Če k temu dodam že prikazane razmere v Z Aziji, vidimo, da se bo število potencialnih migrantov v Evropo v prihodnje še povečalo, kar bo morala MP EU in širše Evrope upoštevati (Malačič 2007). To pa hkrati pomeni, da je treba MP tesneje povezati s PP, kar v EU pomeni, da bo treba ustvariti razmere, v katerih bodo ljudje želeli rojevati toliko otrok, da bo zagotovljeno dolgoročno nemoteno obnavljanje prebivalstva. Treba je opustiti stališče, da rodnost v EU ni pomembna in jo bo mogoče nadomestiti s priselitvami iz prenaseljenih regij drugih celin. Demografske študije so pokazale, da bi bilo preveliko tako pridobljeno priseljevanje politično nevzdržno in bi povzročilo številne težave (UN 2000; Coleman 2007). Priseljevanje v EU naj dolgoročno ostane na vzdržni ravni, to pa naj določa sposobnost integracije priseljencev v evropsko družbo. Gotovo pa drži, da EU ne bo mogla sprejeti ne samo vseh, ampak niti ne večjega števila tistih, ki si bodo v prihodnjih desetletjih prizadevali priseliti vanjo. Zato je pomemben sestavni element MP EU način, kako zadržati ljudi iz drugih celin v njihovem izvornem okolju. To bo najlaže doseči s podporo gospodarskemu in družbenemu razvoju, ob političnih in okoljskih krizah pa tudi z oblikovanjem varnih območij in pomoči v obliki hrane in drugih življenjskih potrebščin. MP EU bi morala predvideti tudi odziv na morebitne okoljske katastrofe, ki bi v kratkem času zahtevale preselitev več sto milijonov ljudi. V razmerah intenzivnih klimatskih sprememb je s takšno možnostjo treba računati, čeprav bi si v tem primeru EU delila breme z drugimi regijami in državami sveta.

MP EU si bo lahko prizadevala nekatere svoje dosežke uveljaviti tudi v širšem globalnem okolju, vendar med njimi še dolgo ne bo prostega pretoka oseb, kot je v šengenskem območju. Že ob migracijski krizi 2015/16, ki v primerjavi z morebitnimi prihodnjimi krizami verjetno ni bila posebej velika, se je pokazalo, da je najprej ogroženo načelo prostega pretoka oseb. Dokler ne bo na svetu ene same vlade ali pa enakomerne in visoke gospodarske razvitosti, 
bo treba živeti s pravico držav, da na svoje ozemlje sprejmejo ali ne sprejmejo oseb, ki bi si to želele. To pa pomeni, da bo MP držav še naprej izrazito selektivna. Še naprej bodo obstajale osnovne vrste in delitve mednarodnih migracij, MP EU pa jih bo morala upoštevati. Treba je poiskati učinkovitejše načine preprečevanja nezakonitih migracij in trgovine z ljudmi ter olajšati in povečati prihod zakonitih migrantov v EU. V Evropi bo treba prijazneje sprejeti slednje, predvsem ekonomske imigrante, da najboljši med njimi, glede na izobrazbo in nekatere druge kriterije, ne bi še naprej odhajali v ZDA. Vojno za talente, ki poteka v modernem svetu, je Evropa v zadnjih letih izgubljala. Izboljšati je treba politiko modre karte, da bo njena uspešnost primerljiva s politiko zelene karte $v$ ZDA. Ker je težko napovedati prihodnji razvoj na trgu dela in v svetu dela nasploh, je treba mlade imigrante pritegniti v evropske šole in na univerze, jim finančno omogočiti šolanje ter spodbujati kroženje strokovnjakov med EU in nerazvitimi izvornimi državami. EU bi morala spodbujati izvoz kapitala in neposrednih investicij v države s številnimi potencialnimi emigranti. To bo prineslo delovna mesta in zadržalo ljudi v domačem okolju, hitrejši gospodarski razvoj pa bo pomagal modernizirati manj razvite države in prispeval $\mathrm{k}$ večji politični stabilnosti. EU lahko $\mathrm{k}$ temu dodatno prispeva $\mathrm{z}$ odprtjem lastnih trgov za kmetijske in druge proizvode iz izvornih držav potencialnih imigrantov. Na tem področju se je EU doslej preveč zapirala in se naslanjala na težavna pogajanja v Mednarodni trgovinski organizaciji.

EU si želi v prihodnje bremena in stroške pomoči beguncem, iskalcem zatočišča in razseljenim osebam ustrezneje in pravičneje porazdeliti med države članice (Dossier Migration 2015: 30-43) in doseči spoštovanje mednarodnih obveznosti. Ker dosedanja v Dublinu dogovorjena politika ni bila kos migracijski krizi 2015/16, jo je treba dopolniti in izboljšati. Rešitve morajo biti zakonite, spoštovanje pravne države je temelj evropskega načina življenja in združevanja. Evropa ne more dovoliti množičnega nezakonitega prestopanja svojih meja in prostega gibanja priseljencev po celini. Države ob zunanjih mejah EU in šengenskega območja bodo vedno bolj izpostavljene prihodu nezakonitih migrantov, tihotapljenju ljudi in prihodom beguncev, ki jih bodo sprožale nove vojne in krize v soseščini ali drugje po svetu. Ker je breme migracij za te države že v sedanji krizi preveliko, v prihodnosti pa se utegne še povečati, naj MP EU določi načine zagotavljanja in uveljavljanja ustrezne solidarnosti med članicami EU.

Med migracijsko krizo na balkanski poti in pred tem na obalah Sredozemskega morja je solidarnost med članicami EU odpovedala. Veliko sta k temu prispevali nedodelanost in odsotnost MP EU, pa tudi veliko število migrantov, kar je bilo v EU podcenjeno. Politiki so podcenili tudi politični učinek množičnih smrtnih in drugih nesreč na morju. To se je še stopnjevalo, ko so se smrtne nesreče začele dogajati na cestah, v predorih in tovornjakih na ozemlju članic EU. Solidarnost je odpovedala tudi pri predlogu kvot, s katerimi bi porazdelili nezakonite migrante in prosilce za azil, ki so že bili na ozemlju EU, med članice EU. Čeprav mora MP EU natančneje določiti vlogo in način izvedbe kvot, pa so kvote bolj začasna kot trajna rešitev težav, saj narava migracij kaže, da migrantov ni mogoče prisilno zadržati dalj časa tam, kjer ti ne želijo ostati. Z MP EU je treba natančno razmejiti začasne in trajne ukrepe. Začasni ukrepi morajo biti sestavni del dobre MP že zaradi nepredvidljivosti prihodnjih migracijskih gibanj in kriz. Hkrati pa ti ne bi smeli le gasiti požarov in nadomeščati dobro zasnovane in vodene dolgoročne MP. V številnih državah se je pokazalo, da je zelo drago begunce, iskalce zatočišča in razseljene osebe nameščati v posebne centre in jih tako izločati iz lokalne skupnosti. Tudi zaradi napadov nanje mora MP EU dopuščati in predvideti alternativne načine njihove nastanitve, stanovanjsko vključenost v lokalno 
skupnost pa je treba dopolniti s pravico do dela in zaposlitve. Tako se bodo tujci najhitreje integrirali, stroški MP pa se bodo zmanjšali, saj bodo tujci lahko sami poskrbeli zase.

MP EU si naj prizadeva najti načine učinkovitega preprečevanja trgovine z ljudmi. Zločine, ki se dogajajo na tihotapskih migrantskih poteh na morju in kopnem, je treba preganjati in kaznovati. Višino kazni in tveganj za tihotapce je treba močno povečati, saj so zaslužki previsoki, tveganja pa premajhna. Prav tako bo treba povečati učinkovitost policije tako v EU kot drugje v Evropi, pa tudi spodbuditi oblasti v izvornem okolju za preganjanje in kaznovanje tihotapcev. EU mora pomagati graditi politično stabilnost v svoji soseščini in širše, če je treba, tudi z vojaškimi sredstvi, saj brez reda in politične stabilnosti ni mogoče uresničevati ustrezne in učinkovite MP.

Demokratična evropska družba mora s svojo MP poiskati humane načine vračanja nezakonitih priseljencev, ki ne izpolnjujejo pogojev za sprejem, v njihovo izvorno okolje ali njegovo soseščino. Dosedanje rešitve so preveč temeljile na policijskih metodah. Kjer je le mogoče, bi bilo treba te metode kombinirati z ekonomsko pomočjo in ekonomskimi spodbudami. Grobo orisani okvir MP EU bo treba poglobiti in preveriti v širših strokovnih in političnih razpravah ter demokratično sprejeti v državah članicah EU in Evropskem parlamentu. Dobro organizirana in učinkovita EU si ne bo mogla na daljši rok privoščiti previsokih stroškov gašenja požarov ob izbruhih kriz in nepreverjenih začasnih rešitvah. Sredstva namreč veliko bolj potrebuje za prihodnji razvoj, ki bo kos izzivom bliskovitih sprememb v globalnem svetu in bo hkrati v interesu državljanov EU, pa tudi vseh tistih, ki bodo po zakoniti poti prišli v EU in se integrirali v evropsko družbo. Evropejci in prihodnji imigranti v Evropo, ki jih bo ta sprejemala več kot v preteklih desetletjih, ne bo pa mogla sprejeti vseh, ki bi si to želeli, imajo dolgoročno enak interes. Čeprav naj bi bile imigracije v EU priložnost za večino, moramo hkrati vedeti, da bodo zaradi ekonomskih zakonitosti za del Evropejcev tudi škodljive. Na trgu dela se običajno znižajo plače in poslabšajo zaposlitvene možnosti domačinov, ki jim neposredno konkurirajo priseljenci (Chiswick 2005: xvi). V interesu Evropejcev in imigrantov je uspešna, učinkovita in demokratična Evropa, ki bo zagotavljala blaginjo v njej živečih ljudi. Imigranti si močno želijo, da bi bili sprejeti, pri čemer pa je Evropa žal največkrat odpovedala. V prihodnje lahko pričakujemo večje poenotenje MP v razvitih državah, sami imigranti pa se bodo morali bolj prilagoditi evropskim vrednotam in opustiti številne $z$ evropskim pravnim redom nesprejemljive prakse.

\section{SKLEP}

Migracijska kriza v Evropi 2015/16 je pokazala, da EU in širša Evropa nista bili pripravljeni na nepričakovano odprtje balkanske poti priseljevanja in hiter razpad mednarodnega pravnega sistema, vključno z zakonodajo EU za sprejemanje različnih migrantov. Informacije o odprtju poti so se hitro razširile v begunska taborišča v Z Aziji in širše, kar je sprožilo velik porast tihotapljenja ljudi in prihod številnih nezakonitih migrantov v Evropo. V drugi polovici septembra 2015 se je njihova pot preusmerila tudi v Slovenijo. Hkrati pa je, kljub dogovoru med EU in Turčijo spomladi leta 2016, v prihodnosti prihod imigrantov nemogoče predvideti.

Ob prihodu številnih nezakonitih imigrantov na balkanski poti se je pokazalo, da je EU brez MP, ki bi učinkovito in humanitarno primerno reševala nastale probleme. V zadnjih dvajsetih letih je bila v EU zanemarjena tako PP kot njen sestavni del MP, hkrati pa je 
v Z Aziji in S Afriki prebivalstvo hitro naraščalo. Ta rast je skupaj z lokalnimi vojnami in krizami povečevala število potencialnih migrantov v Evropo; v naslednjih desetletjih se bo to število še povečalo. EU se že vsaj deset let zaveda pomena PP in MP, čeprav ti ostajata v pristojnosti držav članic. Migracijska kriza je pokazala, da bosta morali biti ti politiki prioriteta in da ju bo treba obravnavati povezano. Okvirno orisani model MP v pričujočem besedilu bo treba poglobiti in preveriti v širših strokovnih in političnih razpravah ter sprejeti v organih odločanja EU in njenih članic. V Evropi je v šengenskem območja uresničen prost pretok ljudi, česar drugje v svetu še dolgo ne bo mogoče uresničiti. Migracijska kriza 2015/16 in morebitne prihodnje krize tega dosežka ne smejo ogroziti. Za uresničitev prostega gibanja ljudi po celem svetu pa bo potrebnega še veliko časa, saj bi bilo treba najprej doseči enakomerno razvitost in morda celo oblikovanje svetovne vlade oziroma ukinitev državnih in širših regionalnih meja.

\section{LITERATURA IN VIRI}

Akcijski program Mednarodne konference o prebivalstvu in razvoju, Kairo, 5. 9. do 13. 9. 1994. Ljubljana: Ministrstvo za delo, družino in socialne zadeve.

Belloni, Milena (2016). Refugees as Gamblers: Eritreans Seeking to Migrate Through Italy. Journal of Immigrant and Refugees Studies 16/1, 104-119.

Boeri, Tito idr. (2002). Immigration Policy and the Welfare Systems. New York: Oxford University Press.

Chiswick, Barry R. (2005). The Economics of Immigration. Cheltenham, UK, Northampton, MA, USA: Edward Elgar.

Coleman, David (2007). Immigration and Ethnic Change in Low - Fertility Countries: A Third Demographic Transition in Progress? Migration and Development. International Migration of Population. Russia and Contemporary World (ur. Vladimir Iontsev). Moskva: Lomonosov Moscow State University, Faculty of Economics, 10-42. (Besedila v knjigi so prevedena tudi v ruščino.)

Demeny, Paul (2003.) Population Policy Dilemmas in Europe at the Dawn of the Twenty-First Century. Population and Development Review 29/1, 1-28.

European Commission (2005a). On an EU Approach to Managing Economic Migration, Green Paper. Bruselj: European Commission, 11. 1. 2005.

European Commission (2005b). Confronting Demographic Change: A new Solidarity between the Generations, Green Paper. Bruselj: European Commission, 16. 3. 2005.

European Commission (2007). Europe's Demographic Future: Facts and Figures on Challenges and Opportunities. Bruselj: European Commission.

European Commission (2015). Dossier Migration: Putting Europe to the Test. Comission en direct. Bruselj: European Commission, 25. 10. 2015.

European Demographic Data Sheet 2014 (2014). Dunaj: Wittgenstein Centre, Vienna Institute of Demography, Austrian Academy of Sciences and International Institute for Appllied Systems Analysis.

Evropska komisija (2008). Migracije in mobilnost: Izzivi in priložnosti za izobraževalne sisteme v EU, Zelena knjiga. Bruselj: Evropska komisija, 3. 7. 2008.

Evropska komisija (2016). EU in begunska kriza. Bruselj: Evropska komisija, 1-4. 
Geddes, Andrew (2001). International Migration and State Sovereignty in an Integrating Europe. International Migration. Special Issue: International Migration Policies 39/6, 21-42.

Global Migration Data Sheet 2005-10 (2014). Dunaj: Wittgenstein Centre, Vienna Institute of Demography and Austrian Academy of Sciences.

Lutz, Wolfgang idr. (2003). Europe's Population at a Turning Point. Science 299, 1991-1992.

Malačič, Janez (2006). Demografija: Teorija, analiza, metode in modeli, 6. izdaja. Ljubljana: Ekonomska fakulteta Univerze v Ljubljani.

Malačič, Janez (2007). The Role of Migration in Modern Demographic Regime. Migration and Development. International Migration of Population. Russia and Contemporary World (ur. Vladimir Iontsev). Moskva: Lomonosov Moscow State University, Faculty of Economics. 100-113. (Besedila v knjigi so prevedena tudi v ruščino.)

Malačič, Janez (2009a). The Borders of the European Union and Neighbouring Areas: The Importance of Demographics (ur. Mateja Jančar), Where are the Limits of the European Union? Ljubljana: Inštitut Jožeta Pučnika in CES.

Malačič, Janez (2009b). The Demographic Development in the European Union and Neighbouring Hinterland: The Importance of Growing Imbalances. Soočanje z demografskimi izzivi 2009. Informacijska družba - IS 2009, Zvezek B (ur. Janez Malačič in Matjaž Gams). Ljubljana: Institut Jožef Stefan, 22-28.

Malačič, Janez (2013). Prebivalstvena politika Slovenije: Od pasivnega prilagajanja spremembam k aktivnemu oblikovanju vzdržnega obnavljanja prebivalstva. Soočanje $z$ demografskimi izzivi 2013. Informacijska družba - IS 2013, Zvezek B (ur. Janez Malačič in Matjaž Gams). Ljubljana: Institut Jožef Stefan, 27-32.

Massey, Douglas S. (2007). Toward a Comprehensive Model of International Migration. Migration and Development. International Migration of Population. Russia and Contemporary World (ur. Vladimir Iontsev). Moskva: Lomonosov Moscow State University, Faculty of Economics, 126-148. (Besedila v knjigi so prevedena tudi v ruščino.)

Pison, Gilles (2015). The Population of the World 2015. Population and Societies 525. Pariz: INED, 1-8.

Resolucija o imigracijski politiki Republike Slovenije (1999). Ljubljana: Ur. list RS, št. 40/99. Resolucija o migracijski politiki Republike Slovenije (2002). Ljubljana: Ur. list RS, št. 106/02. United Nations (UN) (2000). Replacement Migration: Is It a Solution to Declining and Ageing Populations? New York: United Nations Population Division, ESA/P/WD,160.

World Population Prospects, 2015 Revision (2015). United Nations Population Division, New York, http://esa.un.org/undp/wpp/DVD (27. 1. 2016). 


\section{SUMMARY}

\section{MIGRANT CRISIS AND MIGRATION POLICY IN EUROPE: FROM DEMOGRAPHIC IMBALANCES AND POLITICAL TURMOIL TO THE INCREASING MIGRATION STREAM} Janez MALAČIČ

European migrant crisis 2015/16 has shown serious weaknesses of the EU legal system dealing with refugee protection, asylum seekers and immigration. In spite of the fact that immigration has remained legally in the domain of EU member states the crisis exposed necessity of broader European cooperation in the field of migration and refugee protection. The thesis of the author of the paper is even broader than this. The migrant crisis is a consequence of broader demographic, economic and social situation in Europe, West Asia and North Africa. In the EU migrant crisis is a part of broader population policy (PP) crisis.

Migration policy (MP) is important part of PP. However, the connections between MP and $\mathrm{PP}$ are neglected in practice. In the EU and most of its member states only immigration policy attracts interest of politicians and public in general. PP and MP in its totality are much less developed in spite of the need for positive net migration in the low fertility countries to neutralize serious population ageing and future population decline. Migration processes in general and migrant crisis 2015/16 in particular are connected to huge demographic and economic differences between Europe on one side and West Asia and North Africa on the other side. One of the most important is the difference in the demographic regimes. Europe has modern demographic regime with completed demographic transition, positive net migration, stagnant population growth and population ageing. European hinterland on the other side has transitional demographic regime with high population growth, young population age structure and negative net migration. Demographic imbalances and the differences in economic development push migrants and refugees (in periods of wars, military conflicts, political and social turmoil) towards Europe.

Therefore, EU needs well designed and developed MP and PP for appropriate management of migration processes and sustainable population development in general. The author has outlined basic elements of the sustainable model of MP in the EU. The model needs further development and discussions in professional and broader political circles and institutions. However, the crucial element of the sustainable immigration to Europe is the capability of the European societies to integrate immigrants economically and socially. It is important to know also that flow of the people is one side of the medal only. The other side is export of the capital and direct investments of European countries and companies in the hinterland regions for faster economic development and better employment opportunities there. The EU also needs to lower the costs and to increase efficiency of the migration and refugee protection management. The funds are much more needed for economic and social development and modernization which will enable better life for native Europeans as well as for integrated immigrants in Europe. 